Original Research Article

\title{
Drug utilization study in dengue infection in a tertiary care hospital
}

\author{
Smita Bhandare*, Santoshkumar R. Jeevangi
}

Department of Pharmacology, Mahadevappa Rampure Medical College, Kalaburagi, Karnataka, India

Received: 07 January 2019

Accepted: 29 January 2019

*Correspondence to:

Dr. Smita Bhandare,

Email:drsmitavb@gmail.com

Copyright: (C) the author(s), publisher and licensee Medip Academy. This is an openaccess article distributed under the terms of the Creative Commons Attribution NonCommercial License, which permits unrestricted noncommercial use, distribution, and reproduction in any medium, provided the original work is properly cited.

\begin{abstract}
Background: Dengue fever (DF) is a serious public health problem, gaining global attention because of its morbidity and mortality. Less studies on Drug utilization pattern of DF in India. The present study was undertaken to analyze Drug utilization pattern of dengue infection in a tertiary care hospital.

Methods: A prospective cross-sectional study was conducted for a period of 2 months in a tertiary care hospital and the data was analyzed by using various drug use indicators.

Results: A total of 52 prescriptions were analyzed. Male and female were $(46.16 \%, 53.84 \%)$, A total of 330 drugs were prescribed. $86(26.06 \%)$ antibiotics, $70(21.21 \%)$ antipyretics, $51(15.46 \%)$ antacids, $19(5.76 \%)$ multivitamins, 52 $(15.76 \%)$ anti-emetics and $52(15.76 \%)$ papaya leaf extract was prescribed. 84 $(25.46 \%)$ oral and $246(74.54 \%)$ injectable drugs. IV-fluids given to all patients. $10(19.24 \%)$ were given blood transfusion. 6.17 drugs per prescription. 96\% drugs were prescribed by brand names. High DDD for drugs like diclofenac (184), doxycycline (115), metronidazole (2.5), pantoprazole (161.5), rabeprazole (34.6), ondansetron (200) was observed.

Conclusions: Most commonly used drugs are antipyretics, antibiotics, antacids, antiemetic, papaya leaf extract. As the incidence of DF is increasing with epidemics, demand for specific treatment guidelines is in great need. Early recognition of the disease, with a rational approach in case management leads good clinical outcome.
\end{abstract}

Keywords: Dengue fever, Drug utilization pattern, DDD/ATC code

\section{INTRODUCTION}

Dengue is a major public health threat globally. It is an acute viral illness caused by RNA virus of the family Flaviviridae and spread by Aedes mosquitoes. ${ }^{1-3}$ The number of dengue cases has increased 30-fold globally over the past five decades. ${ }^{4,5}$ Dengue is endemic in more than 100 countries and causes an estimated 50 million infections annually. ${ }^{6-8}$ In India the annual incidence is estimated to be 7.5 to 32.5 million. ${ }^{9}$

Individuals infected with dengue exhibit a wide spectrum of clinical symptoms ranging from asymptomatic fever to dreaded complications such as hemorrhagic fever and shock. Acute-onset high fever, muscle and joint pain, myalgia, cutaneous rash, hemorrhagic episodes, and circulatory shock are the commonly seen symptoms. ${ }^{1,10}$ Dengue is distinguished from other infections without laboratory diagnostic tests. ${ }^{11}$

Drug utilization research was defined by WHO in 1977 as the marketing, distribution, prescription, and use of drugs in a society, with special emphasis on the resulting medical, social and economic consequences. Study of drug utilization pattern in a particular setting gives an idea about the prescribing practices and characterizes the early signals of irrational drug use. With the help of WHO prescribed drug use indicators it is possible to analyze drug utilization patterns in our settings. ${ }^{12,13}$ 
The principal aim of drug utilization research is to facilitate the rational use of drugs in Populations i.e. to evaluate whether drugs are properly utilized in terms of efficacy, safety, convenience and economic aspects at all levels in the chain of drug use. Drug utilization research in itself does not necessarily provide answers, but it contributes to rational drug use in important ways. ${ }^{12,14}$

\section{Core drug use indicators ${ }^{13}$}

\section{Prescribing indicators}

- Average number of drugs per encounter

- Percentage of drugs prescribed by generic name

- Percentage of encounters with an antibiotic prescribed

- Percentage of encounters with an injection prescribed

- Percentage of drugs prescribed from essential drugs list or formulary

\section{Patient care indicators}

- Average consultation time

- Average dispensing time

- Percentage of drugs actually dispensed

- Percentage of drugs adequately labelled

- Patients' knowledge of correct dosage

\section{Facility indicators}

- Availability of copy of essential drugs list or formulary

- Availability of key drugs

\section{Complimentary indicators}

- Percentage of patients treated without drugs

- Average drug cost per encounter

- Percentage of drug costs spent on injection.

\section{Anatomic Therapeutic Chemical classification (ATC)/ Defined Daily Dosage $(D D D)^{12-14}$}

Drug utilization studies are powerful tools to ascertain the role of drugs in the society. To achieve this, it is very important to determine the drug use pattern and to monitor the drug use profile using the Anatomic Therapeutic Chemical classification (ATC)/ Defined Daily Dosage (DDD) as a tool for drug utilization in order to improve the quality of drug use. Drug utilization research is an essential part of Pharmacoepidemiology.

A drug classification system represents a common language for describing the drug assortment in a country or region and is a prerequisite for national and international comparisons of drug utilization data, which have to be collected and aggregated in a uniform way. There are two systems of classification - Anatomical Therapeutic classification developed by the European Pharmaceutical Market Research Association and the Anatomical
Therapeutic Chemical (ATC) classification developed by Norwegian researchers. In 1996, WHO recognized the need to develop the ATC/DDD system from a European to an international standard in drug utilization studies.

In the ATC classification system, the drugs are divided into different groups according to the organ or the system on which they act and their chemical, pharmacological and therapeutic groups at five levels.

DDD is the estimated average maintenance dose per day of a drug when used in its major indication. The main purpose of DDD system is to provide a tool for presenting drug utilization studies which would allow the measurement of drug consumption across the therapeutic group. Generally, drugs with a high volume of use, high cost and high frequency of adverse drug events are subjected drug utilization studies.

Various drug utilization studies have been carried out all over the world but there are limited studies addressing drug use patterns in dengue infection in India.

\section{METHODS}

A prospective cross sectional study was carried out in the department of medicine, Basaveshwara Teaching and General Hospital, attached Mahadevappa Rampure Medical College, Kalaburagi, Karnataka, India involving patients above 18 years of age of either sex over a period of 2 months i.e. November and December 2017. A total of 52 patients were recruited for the study based on inclusion and exclusion criteria. Once the prescription was copied and the patients were interviewed as per the WHO Core indicator Guidelines. The prescriptions were analyzed in the Department of Pharmacology for trends of drug use and rationality of prescription and calculation of the WHO core indicators.

\section{The various indicators determined are $e^{12,15}$}

- Prescribing indicators

- Patient care indicators

- Facility indicators

- Complimentary indicators

\section{ATC/DDD system ${ }^{16}$}

DDD /1000/ Day: It was calculated by following formula

Total number of dosage Strength of each Unit prescribed X Dosage unit X 1000

DDD X Duration of study X Total sample size

DDD was calculated as per the guidelines for ATC classification and DDD assignment (February 2018). As given by the WHO Collaborating Center for Drug Statistics Methodology. Oslo, Norway. 


\section{Inclusion criteria}

- $\quad$ Patients $>18 y$ rs of either sex

- Diagnosed dengue positive case.

\section{Exclusion criteria}

- Patients with concurrent infection.

- Fever for evaluation.

\section{Ethical aspects}

The study project was approved by the Instituitional Ethics Committee, MRMC, Kalaburagi, Karnataka, India. Written Informed consent was taken.

\section{Statistical analysis}

The data collected was analysed statistically using descriptive statistics and presented as counts and percentages. Results are depicted in the form of tables.

\section{RESULTS}

A total of 52 prescriptions were analysed in the study. Out of 52 patients $46.16 \%$ (24) were males and $53.84 \%$ (28) were females. Age wise distribution of patients was 33 $(63.46 \%)$ were in $18-30$ years, $12(23.07 \%)$ were in $31-45$ years, $6(11.54 \%)$ were in 46-60 years, and $1(0.02 \%)$ was $>60$ years respectively as shown in Table 1 .

A total of 330 drugs were prescribed. $86(26.06 \%)$ antimicrobials, $70(21.21 \%)$ antipyretics, $51(15.46 \%)$ antacids, $19(5.76 \%)$ multivitamins, 52 (15.76\%) antiemetics and $52(15.76 \%)$ papaya leaf extract was prescribed. IV-fluids was given to all 52 (100\%) patients. $10(19.24 \%)$ were given blood transfusion.

\section{WHO core prescribing indicators}

The prescribing indicators were calculated for all the patients to determine the differences in the prescription (Table 2).

Average number of medications per encounter was 6.17 drugs.

Percentage of drugs prescribed by generic name- $14(4 \%)$ by generic name and rest $316(96 \%)$ drugs were prescribed by brand names.

Percentage of medicines prescribed from hospital formulary were recorded $186(56.36 \%)$ drugs prescribed from essential list and most commonly prescribed drugs were anti-pyretic, antacids, anti-emetics and lastly multivitamins and antibiotics.

Percentage encounter with an antibiotic prescribed recorded was $86(26.06 \%)$ antimicrobials were prescribed namely doxycycline $30 \quad(34.88 \%)$, ceftriaxone 25
(29.06\%), cefotaxime $16(18.60 \%)$ amoxicillin + clavulanic acid 11 (12.79\%), Piperacilline + Tazobactum 3 $(0.034 \%)$ and Metronidazole $1(0.01 \%)$.

Percentage encounter with an injection prescribed was recorded by authors was $246(74.54 \%)$ injectable drugs, $84(25.46 \%)$ oral.

The other drug use indicators are shown in Table 2. Drugs used in dengue infection with DDD/1000/day is shown in Table 3 .

For intravenous (IV) fluids and nutritional supplements, DDD was not given because of greater variation in the dosage given to individual patients (cases).

Carica papaya leaf extract and whole blood doesn't have ATC/DDD code and DDD.

Table 1: Demographic profile.

\begin{tabular}{|ll|}
\hline Patients criteria & Data \\
\hline Total patients & 52 \\
\hline Male: Female & $24(46.16 \%): 28(53.84 \%)$ \\
\hline 18-30 years & $33(63.46 \%)$ \\
\hline 31-45 years & $12(23.07 \%)$ \\
\hline 46-60 years & $06(11.54 \%)$ \\
\hline$>60$ years & $01(0.02 \%)$ \\
\hline
\end{tabular}

Table 2: Prescribing indicators.

\begin{tabular}{|ll|}
\hline Prescribing indicators & Data \\
\hline Average number of drugs per prescription & 6.17 \\
\hline $\begin{array}{l}\text { Percentage of drugs prescribed by generic } \\
\text { name }\end{array}$ & $4 \%$ \\
\hline $\begin{array}{l}\text { Percentage of encounters with an antibiotic } \\
\text { prescribed }\end{array}$ & $26 \%$ \\
\hline $\begin{array}{l}\text { Percentage of encounters with an injection } \\
\text { prescribed }\end{array}$ & $74.54 \%$ \\
\hline $\begin{array}{l}\text { Percentage of drugs prescribed from } \\
\text { essential drugs list or formulary }\end{array}$ & $56.36 \%$ \\
\hline Patient care indicators & Data \\
\hline $\begin{array}{l}\text { Average consultation time } \\
\text { Average dispensing time }\end{array}$ & $\begin{array}{l}11.3 \\
\text { minutes }\end{array}$ \\
\hline $\begin{array}{l}\text { Percentage of drugs actually dispensed in } \\
\text { hospital attached pharmacy }\end{array}$ & $81 \%$ \\
\hline Percentage of drugs adequately labeled & $100 \%$ \\
\hline Patient's knowledge of correct dosage & $72 \%$ \\
\hline Facility indicators & Data \\
\hline Availability of copy of essential drugs list & Yes \\
\hline Availability of key drugs & Yes \\
\hline Complimentary indicators & Data \\
\hline Percentage of patients treated without drugs & 0 \\
\hline Average total drug cost per prescription & Rs.780 \\
\hline Drug cost on injection per prescriptions & Rs.550 \\
\hline
\end{tabular}


Table 3: Utilization of drugs expressed as number of prescription and defined daily dose(DDDs) for a period of five days, DU $90 \%$ (NSAIDs) the number of drugs that account for $90 \%$ of drug use.

\begin{tabular}{|c|c|c|c|c|c|}
\hline Class & $\begin{array}{l}\text { Drug (route of } \\
\text { administration) }\end{array}$ & ATC code & DDD & $\begin{array}{l}\text { Prescriptions (52) } \\
\text { n }(\%)\end{array}$ & DDD/1000/day \\
\hline \multirow{2}{*}{ NSAIDS } & Diclofenac (O/P) & M01AB05 & $0.1 \mathrm{~g}$ & $32(61.5)$ & 184.62 \\
\hline & Paracetamol (O/P) & N02BE01 & $3 \mathrm{~g}$ & $37(71.15)$ & 71.15 \\
\hline Opiods & Tramadol (P) & N02AX02 & $0.3 \mathrm{~g}$ & $1(1.92)$ & 1.28 \\
\hline \multirow{6}{*}{ Antibiotics } & Doxycycline $(\mathrm{P})$ & J01AA02 & $0.1 \mathrm{~g}$ & $30(57.69)$ & 115.38 \\
\hline & Ceftriaxone $(\mathrm{P})$ & J01DD04 & $2 \mathrm{~g}$ & $25(48.07)$ & 96.15 \\
\hline & Cefotaxime $(\mathrm{P})$ & J01DD01 & $4 \mathrm{~g}$ & $16(30.76)$ & 61.54 \\
\hline & $\begin{array}{l}\text { Amoxycilline+ } \\
\text { Clavulanic acid (P) }\end{array}$ & J01CR02 & $3 g$ & $11(21.15)$ & 50.77 \\
\hline & $\begin{array}{l}\text { Piperacilline+ } \\
\text { Tazobactum (P) }\end{array}$ & J01CR05 & $14 \mathrm{~g}$ & $3(5.76)$ & 11.13 \\
\hline & Metronidazole (P) & J01XD01 & $1.5 \mathrm{~g}$ & $1(1.92)$ & 2.56 \\
\hline \multirow{2}{*}{ PPI } & Pantoprazole (P) & $\mathrm{A} 02 \mathrm{BC} 02$ & $40 \mathrm{mg}$ & $42(80.76)$ & 161.53 \\
\hline & Rabeprazole (P) & A02BC04 & $20 \mathrm{mg}$ & $9(17.30)$ & 34.62 \\
\hline Anti-emetic & Ondansetron $(\mathrm{P})$ & A04A401 & $16 \mathrm{mg}$ & $52(100)$ & 200 \\
\hline $\begin{array}{l}\text { Nutritional } \\
\text { supplements }\end{array}$ & Multivitamins (P) & $\mathrm{A} 11 \mathrm{AB}$ & $20 \mathrm{mg}$ & 17 (32.69) & - \\
\hline \multirow{4}{*}{ IV-Fluids } & Normal saline $(\mathrm{P})$ & B05BB & - & $37(71.15)$ & - \\
\hline & $\begin{array}{l}\text { Dextrose normal } \\
\text { saline }(\mathrm{P})\end{array}$ & В05BВ & - & $25(48.07)$ & - \\
\hline & Dextrose $(\mathrm{P})$ & B05BB & - & $16(30.76)$ & - \\
\hline & Ringer lactate $(\mathrm{P})$ & B05BB & - & $30(57.69)$ & - \\
\hline \multicolumn{2}{|c|}{ Carica papaya Leaf extract $(\mathrm{O})$} & - & - & $38(73.07)$ & - \\
\hline \multicolumn{2}{|c|}{ Blood transfusion $(\mathrm{P})$} & _. & - & $10(19.23)$ & - \\
\hline
\end{tabular}

Diclofenac-M01AB05: M-musculo-skeletal system; M01-Anti-inflammatory and anti-reumatoid products, M01A- Anti-inflammatory and Anti-Rheumatoid system,Non-steroids; M01AB- Acetic acid derivatives and related substances;M01 AB05- Diclofenac.

\section{DISCUSSION}

Drug utilization research helps use to understand the number of patients exposed to specified drugs within a given time period, the extent of use at a certain moment and/or in a certain area, the pattern or profile of drug use and the extent to which alternative drugs are being used to treat particular conditions, It can be used in the application of quality indicators to patterns of drug utilization. ${ }^{14,15}$

In the present study $46.16 \%$ were males and $53.84 \%$ were females while contrary in a study by, Hafeez et al, males were more than females. ${ }^{17}$ Most common age group affected were between 18-45 years. This is in comparison with previous study. ${ }^{17}$ It is attributed to the changes in locations where disease transmission takes place.

In the management of dengue fever, priority treatment included intravenous fluids. This was similar to previous studies Hafeez et al, Rani $\mathrm{U}$ et al. $^{17,18}$ Intravenous rehydration has been shown to reduce the case fatality rate to less than $1 \%$ of severe cases. ${ }^{19}$ Antimicrobials were the most commonly prescribed medications in our study which was comparable with study done by Beg MA. ${ }^{20}$ The use of antimicrobials was done to prevent secondary bacterial infections.

Prescription of antipyretics, antacids, multivitamins and antiemetic was mainly for symptomatic management of DF as seen in study by Beg MA. ${ }^{20}$

Papaya leaf extract drug is prescribed for patients in our study. It is rich in enzymes like carpaine and a glucoside named carposide, drinking $30 \mathrm{ml}$ of papaya left extract helps in increasing the platelet count. The mechanism involved in platelet rise is not clear. It is available in the form of tablets and syrups and have less side effects. It is contraindicated in people who are allergic to papaya. DDD/ATC code of papaya leaf extract is not available as it is new drugs. ${ }^{21}$

The most commonly preferred route of administration was parenteral route. Since majority of dengue patients will have gastrointestinal disturbances like nausea and vomiting the prescription preference to parenteral formulations was justified. This was similar to previous study. ${ }^{17}$ Average number of medications per prescription was 6.17 drugs in the present study, it is higher as compared to previous study 
average number of drugs per prescription is an important index of prescription audit. ${ }^{18}$ Mean number of drugs prescribed per prescription should be kept as low as possible to prevent the drug-drug interactions, unwanted effects and the additional cost.

Most of the drugs were prescribed by their respective brand names. Prescription of drugs by their generic names helps in the identification of the products, making it easier for the prescribers, dispensers and users to choose between other alternatives competing in terms of quality, price or convenience. $22-24$ Hence the generic drug prescriptions should be increased over prescriptions with branded drugs.

Consultation time and dispensing time are important for better patient compliance. Adherence to the treatment helps in better patient outcome, less therapeutic failures, decrease the cost of the treatment. $81 \%$ of the drugs were dispensed from hospital pharmacy as most of the drugs used in treatment were for symptomatic purpose. Total drug cost per prescription is Rs. 780 and average drug cost of injections per prescriptions is Rs. 550. Most of the drugs used were injectable as vomiting was chief complaint among most of the patients. This doesn't include the cost of complete treatment which includes use of IV fluids, blood transfusion, hospital stay, transportation, feeding etc

Utilization of drugs expressed as number of prescription and defined daily dose (DDD) for a period of five days, DU $90 \%$ the number of drugs that account for $90 \%$ of drug use. High DDD for drugs like diclofenac (184), doxycycline (115), metronidazole (2.5), pantoprazole (161.5), rabeprazole (34.6), ondansetron (200) was observed. ${ }^{16}$ For drugs like IV-fluids, multivitamins, blood, papaya leaf extract DDD was not given due to greater variation. As papaya leaf extract is a new drug and DDD/ATC code is not allotted so it is not possible to calculate and compare with standard WHO daily defined dose and prescribed daily dose.

The main aim of DDD system was to provide a tool for presenting drug utilization studies, which would allow the measurement of drug consumption across the therapeutic group. The DU 90\% methodologies (combined by ATC/DDD) have not been widely used as tools for measuring the qualitative and quantitative drug consumption in India.

It may be concluded that, the drugs used in the treatment of dengue infection is only to treat symptomatically but doesn't have specific treatment. There is the need of specific treatment for the conditions. The results of this study indicate that there is a considerable scope for improving the prescribing habits according to rational drug use and to provide a feed back to the hospital authorities.

The limitations of the study are as papaya leaf extract is a new drug and DDD/ATC code is not allotted so it is not possible to calculate and compare with standard WHO Daily defined dose and prescribed daily dose.

\section{CONCLUSION}

Early recognition of the disease leads to a rational approach to case management and a good clinical outcome. Commonly used drugs are antipyretics, antibiotics, antacids, antiemetic, papaya leaf extract for symptomatic treatment. As the incidence of dengue infection is increasing with epidemics, demand for specific treatment guidelines and vaccine is in great need.

The incidence of polypharmacy is high, the generic is low, and the essential drug prescription is high. The prescription by generic should be promoted more for cost effective treatment. There is considerable scope for improving the prescribing habits according to rational drug use and provide a feed back to the hospital authorities.

\section{Funding: No funding sources}

Conflict of interest: None declared

Ethical approval: The study was approved by the Institutional Ethics Committee

\section{REFERENCES}

1. Hasan S, Jamdar SF, Alalowi M, Al Ageel Al Beaiji SM. Dengue virus: A global human threat: Review of literature. J Int Soc Prevent Comm Dent. 2016;6(1):16.

2. Hombach J. Vaccines against dengue: a review of current candidate vaccines at advanced development stages. Pan Am J Public Health. 2007;21:254-60.

3. Gubler DJ. Epidemic dengue/dengue hemorrhagic fever as a public health, social and economic problem in the 21st century. Trends Microbiol. 2002 Feb;10(2):100-3

4. World Health Organization Dengue: Guidelines for Diagnosis. Treatment, Prevention and Control: New Edition. World Health Organization: Geneva. 2009. Available https://www.who.int/rpc/guidelines/9789241547871/ en/.

5. Halstead SB, Suaya JA, Shepard DS. The burden of dengue infection. Lancet. 2007 Apr 28;369(9571):1410-1.

6. Lam SK, Burke D, Gubler D, Méndez-Gálvan J, Thomas L. Call for a World Dengue Day. Lancet. 2012;379(9814):411-2.

7. Bhatt S, Gething PW, Brady OJ, Messina JP, Farlow AW, Moyes CL, et al. The global distribution and burden of dengue. Nature. 2013 Apr;496(7446):504.

8. Brady OJ, Gething PW, Bhatt S, Messina JP, Brownstein JS, Hoen AG, et al. Refining the global spatial limits of dengue virus transmission by evidence-based consensus. PLoS Neglected Trop Dis. 2012 Aug 7;6(8):e1760.

9. Gupta N, Srivastava S, Jain A, Chaturvedi UC. Dengue in India. Indian J Med Res. 2012;136:373-90.

10. World Health Organization Dengue and severe dengue. Geneva. 2003. Available at: http://www.who.int/mediacentre/factsheets/fs117/en/. 
11. Simmons CP, Farrar JJ, Nguyen VV, Wills B. Dengue. N Engl J Med. 2012;366:1423-32.

12. World Health Organization: Introduction to Drug Utilization Research. 2003;1-49. Available at: http://apps.who.int/medicinedocs/pdf/s4876e/s4876e. pdf

13. Birkett D, Smet PD, Adjei DO, Trolin I, Bergman U, Strom $\mathrm{H}$, et al. Introduction to Drug Utilization Research. WHO. 2003:6-9. Available at: http://www.whocc.no/filearchive/publications/2010g uidelines.pdf.

14. WHO. How to investigate drug use in health facilities: selected drug indicators, action program on essential drugs (DAP), Geneva. 1993:12-25. Available at: http://apps.who.int/medicinedocs/en/d/Js2289e/.

15. Karande S, Sankhe P, Kulkarni M. Patterns of prescription and drug dispensing. Indian $\mathrm{J}$ Pediatr. 2005 Feb 1;72(2):117-21.

16. WHO Collaborating Centre For Drug Statistics Methodology: ATC index with DDDs 2002.Oslo: World Health Organisation, 2002. Available at: http://www.whocc.no/filearchive/publications/2010g uidelines.pdf.

17. Hafeez AK, Akheel MA, Ashfaque A, Meera NK. Prescribing pattern for the treatment of dengue in a tertiary care hospital, Bangalore-India. Pharma tutor 2011. Available at: https://www.pharmatutor.org/articles/prescribingpattern-of-treatment-of-dengue-in-tertiary-carehospital-bangalore https://www.pharmatutor.org/articles/prescribingpattern-of-treatment-of-dengue-in-tertiary-carehospital-bangalore.
18. Rani U, Kamath SG, Varun HV, Aithal S, Patil U. Prescribing Patterns in Dengue Fever in Paediatric Patients in a tertiary care hospital: A retrospective cross sectional study. Int $\mathrm{J}$ Pharma Sci Rev Res. 2014;24(2):112-8.

19. Soegijanto S, Budiyanto, Kartika, Taufik, Amor. The monthly changing of the lowest population dengue virus infection in patient at Soerya hospital. Indonesian J Trop Infect Dis. 2011;2(1):20-24.

20. Beg MA. Study on Drug Prescribing Pattern in Dengue Patients in a Tertiary Care Hospital â€"A tool to teach Clinical Pharmacology. J Drug Delivery Therapeut. 2015 Mar 14;5(2):73-6.

21. Dharmarathna SL, Wickramasinghr S, Waduge RN. Does Carica papaya leaf-extract increase the platelet count? An experimental study in a murine model. Asian Pac J Trop Biomed. 2013 Sep; 3(9):720-724.

22. Shalini S, Ravichandran V, Mohanty BK, Dhanraj SK, Saraswati R. Drug utilization studies an overview. Int J Pharmaceut Sci Nanotechnol. 2010;3(1):803-10.

23. Tabish A, Jha RK, Rathod AM, Rathod RM, Gupta VK, Prescribing trend of analgesics in a tertiary health care setup of rural Vidarbha: A critical appraisal RJPBCS. 2012;3(3):566-71.

24. Rahman MS, Begum ZA, Samad MK. Prescribing pattern of non-steroidal anti-inflammatory drugs at outpatient departments of teaching hospitals. Bangladesh J Pharmacol. 2007;2(1):1-6.

Cite this article as: Bhandare S, Jeevangi SR. Drug utilization study in dengue infection in a tertiary care hospital. Int J Basic Clin Pharmacol 2019;8:569-74. 